\title{
交通シミュレーションを活用した 都市高速道路上の救命活動支援に関する一考察

$\begin{array}{lllll}\text { 山 脇 } & \text { 正 } \text { 嗣* }^{*} \text { 白 } & \text { 渡** } \\ \text { 井面 } & \text { 仁 } & \text { 志** } & \text { 保 田 敬 } \text { —** }^{* *}\end{array}$

\section{A Study on Lifesaving Activity on Urban Expressway Network by Traffic Simulation}

by

\author{
Masashi YamaWaKI ${ }^{*}$, Wataru ShIRAKI ${ }^{* *}$, Hitoshi INOMO ${ }^{* *}$ and Keiichi Yasuda ${ }^{* * *}$
}

\begin{abstract}
When traffic accident occurs on urban expressway network, lifesaving activity with emergency car is important that promptly executes arrival at the scene of the accident and transportation to a hospital. The execution of the lifesaving activity requires a lot of time by the cause such as traffic jam after accident occurs. Therefore, the fire fighting organization and the urban expressway organization should examine method of executing prompt the lifesaving activity even when traffic jam occurred by frequently executing the lifesaving training that assumes situation when the accident occurs. However, it is difficult on both sides of time and the cost to actually execute lifesaving activity in urban expressway. Then, in this study, we examined prompt lifesaving activity in urban expressway by using the traffic simulation system developed by authors. Specifically, by reproducing situation that the traffic accident occurs on urban expressway and the lifesaving activity executes with the system, we measured the arrival time that emergency car arrives at the scene of the accident. And, we examined the expected lifesaving effects by using the concept of Golden Hour Principle that shows relation between passage time since the injury and mortality rate, we made the problem of the present lifesaving activity clear. In addition, we proved that a lifesaving possibility improved by shortening time that the emergency car enters in the expressway.
\end{abstract}

Key words : Traffic simulation, Urban expressway, Traffic accident, Rescue activity, Golden hour principle

\section{1 緒}

\section{言}

高速道路は一般道路よりも速度制限が緩和されている ため, 追突事故等の自動車事故が発生した場合, 受傷者 は高エネルギー外傷を受け，死亡率が一般道路の事故発 生時よりも高くなる。攵のため, 事故発生後に受傷者を いかに早く救急病院まで搬送するかが，救命活動を行う 上で重要になる．高速道路における迅速な救命活動の一 つとしてドクターヘリコプターの利用が挙げられる。 日 本に打いては，1990年代から実験運航が行われ，关の有 効性が確かめられてからは, 各医療機関や消防機関に打

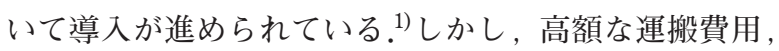
十分な数の医師の確保, ヘリポートの不足等, 解決しな ければならない課題が多数存在するため, 全国的な導入 には至っていない2.2また，地方高速道路よりも遥かに交 通量の多い大都市圈の都市高速道路に扑いては, 事故発 生後に大規模な渋滞発生が予測されるため, 離着陸場所 の確保の困難さから, ドクターヘリコプターによる救命 活動の実施は一層困難である.

そこで, 都市高速道路に打ける事故発生時には, 救急 車両による救命活動を優先し, 事故現場への到着から, 病院への搬送を迅速に行うことが重要である。しかし，
前述の渋滞の問題点等から救命活動の実施は時間を要す ると考えられるため, 各消防機関や都市高速道路機関は, 常日頃から事故発生時を想定した救命訓練を実施し，啮 滞時における迅速な救命活動の実施方法を検討しておく 必要がある。しかし, 都市高速道路に損いて実際に救命 訓練の実施は時間的にもコスト的にも困難である。救命 訓練を実施することなく，迅速な救命活動の実施方法を 検討する手法の一つとして, コンピュータ上で車両の交 通行動を再現する交通シミュレーションによるアプロー チが考えられる。シミュレーションでは，様々な事故発 生状況と救命活動の実施状況を想定・再現する事が可能 であり, 実際の救命訓練では実施不可能な自動車事故の 発生を想定できるメリットがある.

近年では, 都市道路網を対象に車両の交通行動を再現 するシミュレーションについて数多くの研究開発が行われ ている。例として, 堀口らによるAVENUE, 飯田らによ

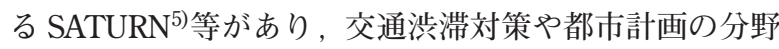
に利用されている。 また, 関西圈の大動脈である阪神高速 道路に扔いても，奥嶋らによる HEROINE ${ }^{6}$ が，実際の交 通管制業務や道路保全等に活用されている。しかし，自動 車事故の発生と救急車両の走行を再現し, 都市高速道路

\footnotetext{
原稿受理 平成 23 年 6 月 1 日 Received June 1, 2011 (C) 2012 The Society of Materials Science, Japan

学生会員 香川大学大学院工学研究科 †761-0396 高松市林町, Graduate school of Eng., Kagawa Univ., Hyashi-cho, Takamatsu, 761-0396

** 正 会員 香川大学工学部信頼性情報システム工学科 †761-0396 高松市林町, Dept. of Reliability-based Information Systems Eng., Kagawa Univ., Hyashi-cho, Takamatsu, 761-0396

*** 正会員 (株) NEWJEC 道路グループ †531-0074 大阪市北区本庄東, NEWJEC Inc., Kita-ku, Osaka, 531-0074
} 
の迅速な救命活動の検討を行うためにシミュレーションを 利用した研究については見当たらないのが現状である。

そこで本研究では，著者らが開発を進めている交通シ ミュレーションシステム7),8)を用いて, 都市高速道路を 対象とした救急車両による迅速な救命活動の実施方法に ついて検討する，具体的には，実際の阪神高速道路を対 象に, システムを用いて救命活動の実施状況を再現し， 救急隊員による救命措置の開始時間を計測することで, 救命措置の開始を遅らせる要因を特定する。さらに, 受 傷後の経過時間と死亡率の関係を示すカーラーの救命曲 線の概念を用いて，期待される救命効果について検討す る. 以上より, 現状の救命活動の問題点を明確化し, 改 善策についての提言を行う事を研究目的とする.

2 交通シミュレーションシステム

著者らが開発を進めているシミュレーションシステム では, 既存の避難シミュレーションに関する研究で主に 利用されている MAS (Multi-Agent System) ${ }^{9)}$ の考え方を 用いて，阪神高速道路を対象に，通常時と被災時に打け るドライバーの心理と行動特性を考慮した車両の交通行 動が再現可能である。また，高速道路管理者による防 災・減災計画構築の支援を行うために，システムには事 故車両・道路破損等の災害の発生, 避難誘導・救命活動 等の被災時対応策の実施状況を再現する機能を実装し， 対応策の効果と有効性を容易に確認可能にしている，以 下にシステムの主な機能を示す。

・車両の行動を可視化することにより容易に行動の傾向 や特徴を把握できる。

・残存車両数や経過時間等がシステム画面上に数值で表 示されるので，刻一刻と変化する状況を定量的に判断 できる.

・様々な状況変化を想定した被災時対応策を検討可能に するため, シミュレーションの途中に打いても，シミュ レーション環境やエージェントの行動規則等を容易に 変更できる.

\section{$2 \cdot 1$ 対象環境}

本システムでは阪神高速道路 1 号環状線をシミュレー ション対象環境として設定している。1号環状線は各路 線を連結する役割を担う重要路線であり，路線内は右回 りの一方通行となっている。また，阪神高速道路を利用 する車両の約 $50 \%$ が集中するため，渋滞の発生が常態化 している状況にある。攵のため，自動車事故や道路破損 等の災害が生じた場合には大規模な渋滞が発生し，受傷 者の救助を行う救急車両の走行を妨害すると予測されて いる.

シミュレーション環境を設定するに当たり，環状線内 (Fig. 2 (a)の狭域空間) と環状線外の道路領域（Fig. 2 (b) の広域空間）の 2 種類の空間を考慮する。環状線内の 個々の車両の詳細な行動を再現する狭域空間と，環状線 外の車両の交通行動を巨視的に再現する広域空間の， ス ケールの異なる 2 種類の空間を相互リンクさせることで, 広範囲の被災状況を再現可能にしている。また，シミュ レーション環境における交通量，各流出ランプ付近の信

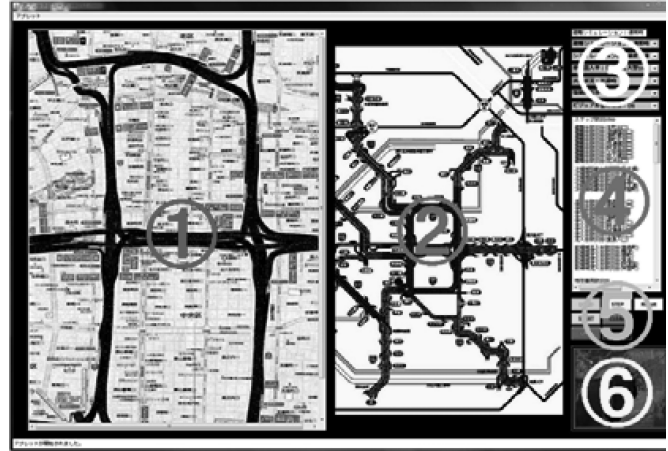
(1) Simulation screen in Loop Route
(2) Simulation screen outside Loop Route
(3) Condition setting part (4) Result display screen
(5) Control button (6) Map display screen

Fig. 1 Traffic simulation system.

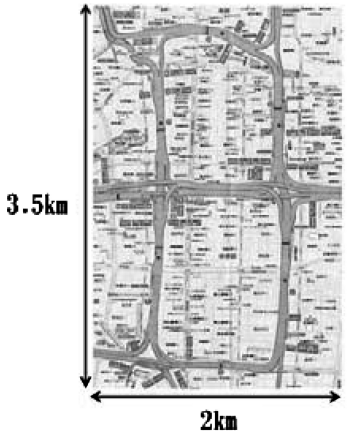

(a) Loop Route

Number of enter ramp : 9 Number of exit ramp : 10

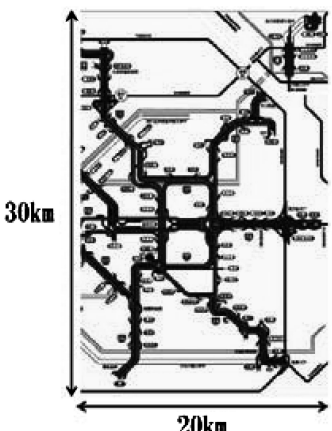

(b) Outside Loop Route Number of enter ramp : 45 Number of exit ramp : 48
Fig. 2 Two kinds of simulation environment.

号制御パラメータ等については，阪神高速道路の平成 16 年 4 月の交通データと実地調査に基づき設定している.

\section{$2 \cdot 2$ シミュレーションモデル}

\section{1) 狭域空間の設定}

狭域空間である環状線内では，高速道路を走行する車 両エージェントを，「普通車両」，「大型車両」，「緊急車 両」の 3 種類に分類する. 各車両エージェントは，自身 の視野範囲内の環境を確認した上で，時間 $\mathrm{t}$ から時間 $\mathrm{t}+1$ の間に，設定した行動規則に従い，走行環境に応じた最 速の速度を選択し移動する。ただし，本シミュレーショ ンモデルにおける 1 ステップは実時間の 2 秒と設定して いる. 各エージェントの具体的な行動規則については参 考文献 7),8)を参照して頂きたい。

\section{2) 広域空間の設定}

環状線外の広域空間に打いて個々の車両の行動を再現 することは，シミュレーション効率や計算機への負荷等の 面から非常に困難である。そこで本研究では，広域空間 を構成する各道路領域を, 複数の車両が存在する道路領 域エージェントとして設定することで，少ない計算量で広 域空間における大規模な交通行動を再現する。各道路領 域エージェントは，自身の状態と，周囲のエージェントの 状態を確認したうえで，狭域空間における車両エージエ ントの行動規則に基づき決定し, 状態を遷移させる. 


\section{$2 \cdot 3$ シミュレーションシステムの精度確認}

シミュレーションシステムの精度を確認するために，実 際の車両事故による渋滞現象と本研究で提案するシミュ レーションシステムを用いた結果を比較する，比較対象 とする現象としては，平成 17 年 3 月 17 日 (木) に 1 号環 状線 1.1 キロポスト（以下 $\mathrm{kp}$ と表示）地点付近で発生し た 5 台が関係する追突事故による渋滞現象 ${ }^{10)}$ を選択し， システムを用いて同じ現象を再現する。シミュレーショ ンの設定条件を以下に示す.

・事故車両の発生：シミュレーション開始と同時

- 事故車両発生箇所と通行状態：1号環状線 $1.1 \mathrm{kp}$ 地点 の 4 車線の内，左側 2 車線が 1 時間通行不能の状態

- 車両混入率：普通車 95\%・大型車 5\%

・初期車両エージェント数：2000 台

実際の渋滞現象の状況を Fig. 3, シミュレーション結 果を Fig. 4 に示す. Fig. 3 より，事故発生から約 1 時間 後に 2 車線の交通規制を実施した結果，事故現場を先頭 とする渋滞が環状線を越え，14 号松原線，15号堺線の 各路線で渋帯現象が発生していることが分かる.Fig. 4 のシミュレーション結果においても，Fig. 3 と同等の結 果が得られており，シミュレーションシステムが実際の 渋滞現象を精度良く再現できていることが確認できる。

\section{3 シミュレーションによる救命活動の検討}

\section{$3 \cdot 1$ 救命活動概要}

本研究で想定する救命活動の概要を Fig. 5 に示す。ま ず，自動車事故発生後に発見者による携帯電話等を用い た連絡が，Fig. 6 に示す環状線付近の 7 つの消防機関の 何れかに入る。連絡を受けた消防機関から救急車両が出 動し，最寄りの流入ランプから高速道路へ進入する。高 速道路上を走行し，事故発生現場に到着する。そして， 救急車両に乗車していた救急隊員による救命措置が開始 されるものとする。

\section{$3 \cdot 2$ 救命活動検討シミュレーション}

上記の救命活動をシミュレーションシステムで再現し， 事故発生から救命措置開始時間を，現状の救命活動の問 題点と改善策について検討する。なお，救命措置の開始

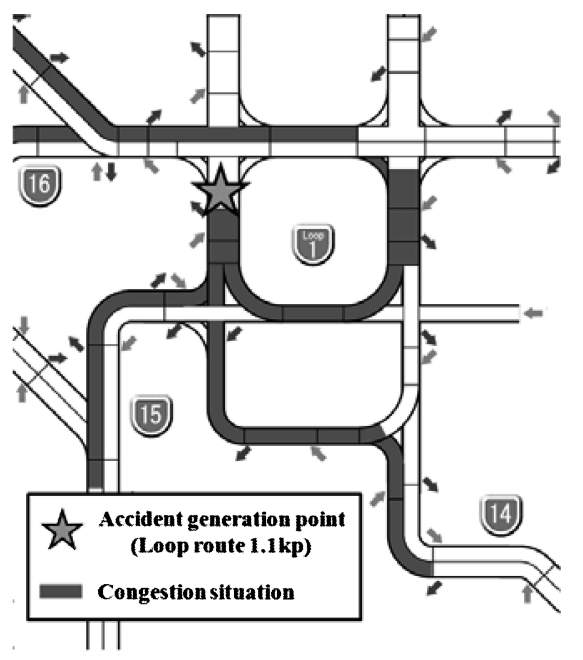

Fig. 3 Real traffic jam phenomenon.

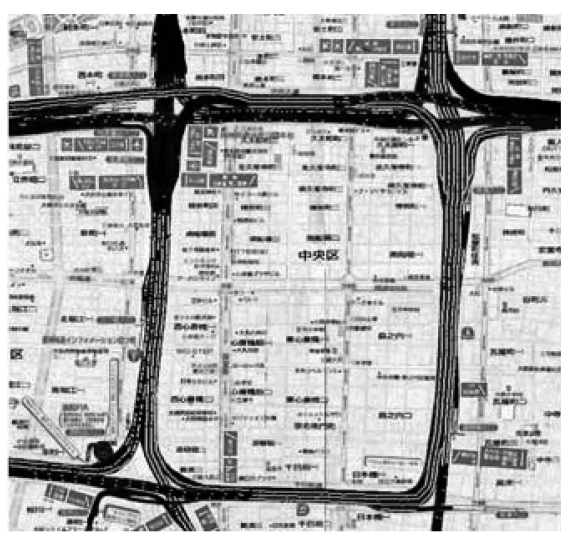

(a) Loop Route

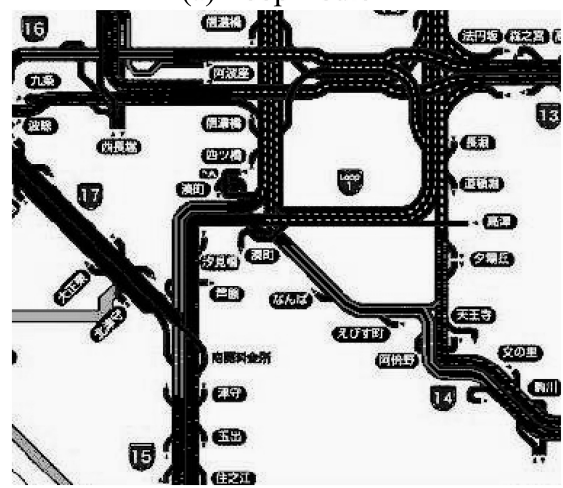

(b) Outside Loop Route

Fig. 4 Simulation result.

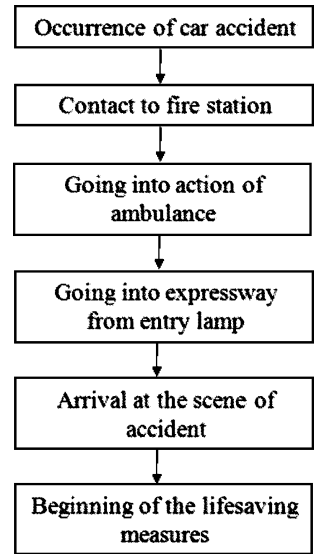

Fig. 5 Concept of lifesaving activity.

は事故現場へ到着後直ちに開始されるものとする。被災 状況と救命活動の実施状況を再現する際には，以下に示 す各車両の行動規則とシミュレーションの初期条件を設 定し，救命措置の開始時間 $\mathrm{T}_{\mathrm{E}}$ を計測する。

1) 救急車両の行動規則

救急車両の行動規則を以下に示す。

・道路交通法に打ける緊急車両の最高制限速度である $100 \mathrm{~km} / \mathrm{h}$ までの速度で移動する。

- 事故車両の $5 \mathrm{~m}$ 以内に接近した場合には，停止して救 命活動を行う。

・高速道路の逆走については，ほとんどの消防機関にお いて禁止しているため考慮しない.3)

・消防機関への連絡時間と一般道路の走行時間を考慮 


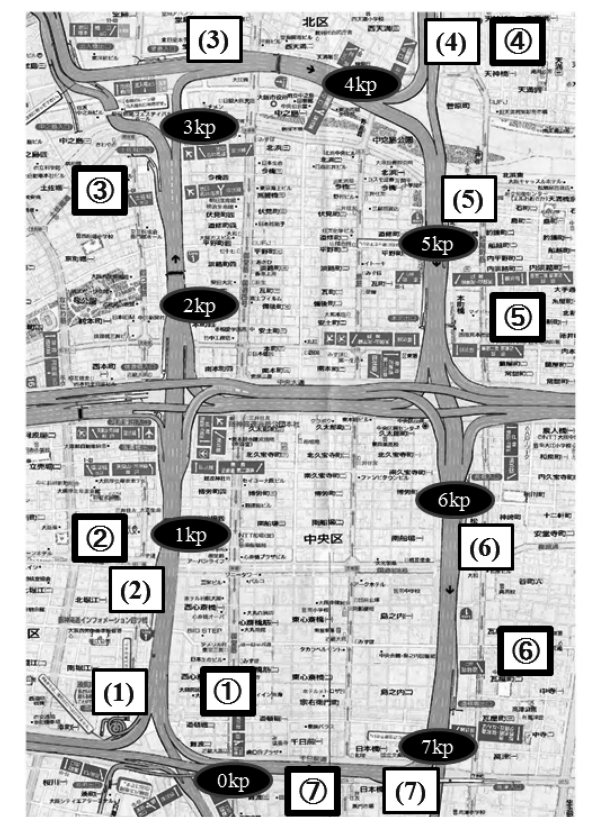

Fire station

(1)Doutonbori

(2)Shinmachi

Enter ramp

(3)Edobori

$\rightarrow 0.45 \mathrm{~km} \rightarrow$

(1) Minatomachi

(2) Yotsubashi

(4) Minamimorimachi $\rightarrow 0.29 \mathrm{~km} \rightarrow$

(3) Douzima

(5)Tyuuou

$\rightarrow 0.96 \mathrm{~km} \rightarrow$

(4)Minamimorimachi

(6) Uemachi

$\rightarrow 1.13 \mathrm{~km} \rightarrow$

(5) Kouraibashi

(7)Minamisakamachi $\rightarrow 0.75 \mathrm{~km} \rightarrow$

6) Nagahori

(7) Koudu

Fig. 6 Positional relationship of fire stations and entry ramps.

し，環状線への流入時間を本論文では事故発生から 10 分後と仮定する。

\section{2) 普通・大型車両の行動規則}

普通・大型車両の行動規則を以下に示す.

・阪神高速道路の最高制限速度である $80 \mathrm{~km} / \mathrm{h}$ までの速 度で移動する。

・ドライバーの多くは，走行中に視野内に事故車両を確 認した場合，危険を察知したり，関心を持ったりする ことにより走行速度を低下させる.7),8)したがって，視 野範囲内に事故車両を確認した場合， $30 \mathrm{~km} / \mathrm{h}$ までの 徐行速度で移動する。

\section{3) シミュレーション初期条件}

以下にシミュレーションの初期条件を示す。

・事故発生時刻：シミュレーション開始と同時
- 事故内容：環状線の $0,1,2,3,4,5,6,7 \mathrm{kp}$ 地点の何れか 1 箇所で自動車事故が発生し，1車線が通行不可能に なった状態を想定

・通行不可能車線：ランダムに決定

- 車両混入率：普通車 $95 \%$ ・大型車 $5 \%$

・初期車両エージェント数：3000 台

- 時間帯：交通量の多い夕方時を想定

- 平均流入車両数： 1200 台 $/ \mathrm{h}$

・ 2 次災害の発生：考慮しない

・シミュレーション回数：30回

$3 \cdot 3$ シミュレーション結果

シミュレーション結果として, Fig. 7 に $\mathrm{T}_{\mathrm{E}}$ の平均值 と標準偏差を示す.Fig. 7 では，事故が発生した kp 地 点別 (Fig. 7 (a)), 救急車両が流入した流入ランプ別 (Fig. 7 (b)) で $\mathrm{T}_{\mathrm{E}}$ の平均值と標準偏差を表示している.

Fig. 7 (a), Fig. 7 (b)より, 全体として $30 \sim 40$ 分程度 で救命措置が開始されていることが分かる。しかし，1kp 地点において事故が発生した場合については， $\mathrm{T}_{\mathrm{E}}$ の值が 他の地点よりも 10 分程大きくなっていることが Fig. 7 (a) より確認できる。シミュレーション実行状況を確認したと ころ, Fig. 8 の 1 車線の道路区間において大規模な渋滞 が発生し，救急車両の走行を妨害することが原因であっ た. 特に, 救急車両が高津流入ランプから高速道路へ流 入した場合は，現場に到着するために必ずこの地点を走 行する必要があるため, $\mathrm{T}_{\mathrm{E}}$ の值が他よりも大幅に大きく なることが，Fig. 7 (b)から確認できる。一方で，湊町流 入ランプから流入した場合では，この地点を走行する必 要が無いため, $\mathrm{T}_{\mathrm{E}}$ の值が他よりも小さくなっていること も Fig. 7 (b)から確認できる．以上より，環状線で事故 が発生した状況に扎いては，Fig. 8の1車線区間が渋滞 を発生させるボトルネック地点となり, 救急車両の走行 を妨害し，救命措置の開始を遅らせる原因になると考え られる。

また，Fig. 7 より，救命措置の開始には少なくとも約 28 分を要することが分かる，総務省消防庁によると，平 成 21 年の救急車両の事故現場到着時間は全国平均で 7.9 分1)であり，それと比較すると，今回のシミュレーショ ンでは事故現場の到着に非常に時間が掛っていることが 確認できる。シミュレーションの実行状況を確認したと ころ, 救急車両が高速道路に流入するまでの 10 分間に
Mean value

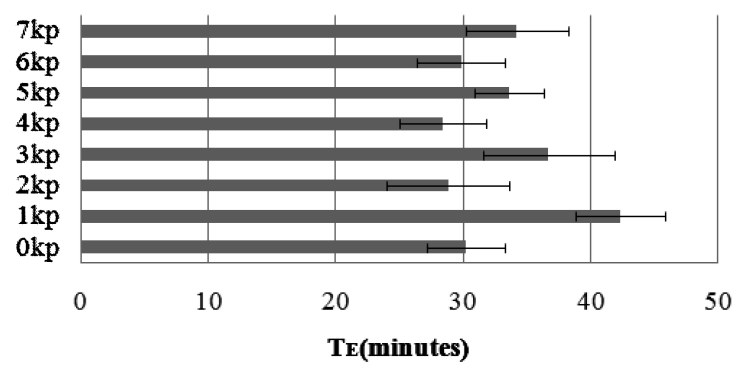

(a) Each kp point

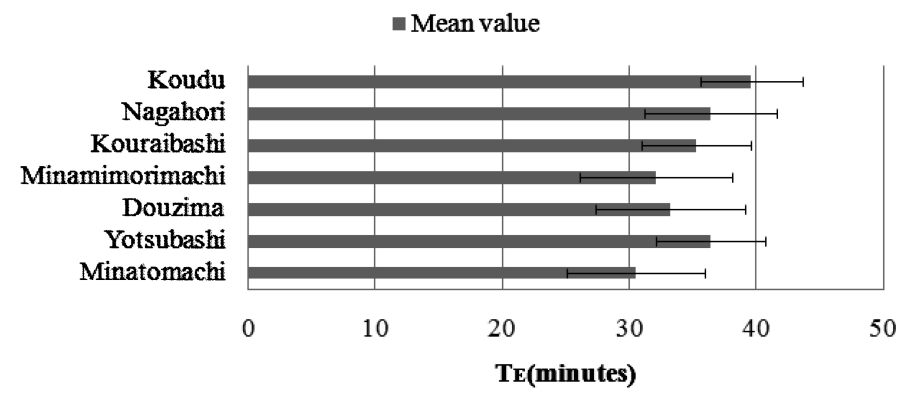

(b) Each enter ramp

Fig. 7 Mean value and standard deviation of $\mathrm{T}_{\mathrm{E}}$ without running support of ambulance. 


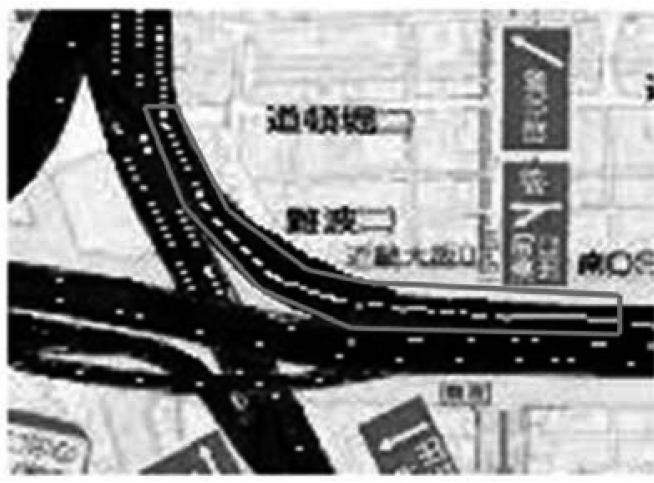

Fig. 8 Road section of one lane.

発生した渋滞により，救急車両の走行速度が低下するこ とがその原因であった。そこで，救急車両の走行速度を 低下させないために，普通・大型車両が視野範囲内に救 急車両を確認した場合，救急車両が走行する車線を避け て移動する行動規則を新たに設定したシミュレーション を実施し，設定前と比較して $\mathrm{T}_{\mathrm{E}}$ の值がどの程度低下す るのかについて検証した。そのシミュレーション結果と して, Fig. 9 に $\mathrm{T}_{\mathrm{E}}$ の計測結果を示す.

Fig. 9 (a), Fig. 9 (b)の結果より, $\mathrm{T}_{\mathrm{E}}$ の值は Fig. 7 と比 較して約 10 分低下し，普通・大型車両が救急車両の走 行を支援しない場合よりも迅速な救命活動が実施可能に なることが確認できる。この結果から，実際の事故発生 時に扔いてもドライバーが，シミュレーションにおける 普通・大型車両と同様に救急車両の走行支援を行うと， 渋滞している高速道路においても，救急車両は迅速に現 場に到着できると考えられる。したがって，事故発生時 には，救急車両用の道路を確保することが重要であり， そのための手順・方法を検討しておく必要がある。また， 日頃から救急車両が走行してきた場合の走行支援方法な らびにその効果を道路情報掲示板や都市高速道路事業の ホームページ等において事前に周知しておくことが，迅 速な救命活動を行う上で重要である。

\section{$3 \cdot 4$ 救命可能性の検証}

本節では, Fig. 9 のシミュレーション結果に基づき，特 定の傷を受けた受傷者に対する救命措置により，受傷者 の救命可能性がどの程度存在するのかについて検討する.

Fig. 10 に事故等による受傷からの経過時間と死亡率 の関係を概念的に表す図として，1981 年にフランスの救

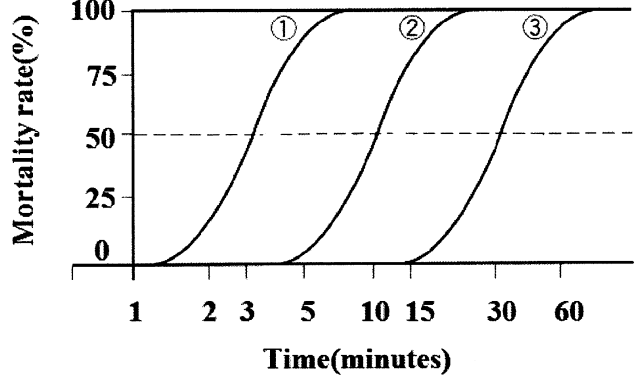

(1) Mortality rate after about 3 minutes of cardiac arrest is $\mathbf{5 0 \%}$.

(2) Mortality rate after about 10 minutes of respiratory arrest is $\mathbf{5 0 \%}$.

(3) Mortality rate after about 30 minutes of excessive bleeding is $\mathbf{5 0 \%}$.

Fig. 10 Golden Hour Principle. ${ }^{1)}$

急専門医師である M. Cara によって報告された「カーラー の救命曲線」1)を示す。カーラーの救命曲線は, 日本で 行われている応急手当講習会に打いても，救命可能性の 理論的根拠となっている. Fig. 10 に示されている死亡率 において，受傷者が多量出血の場合，受傷から 15 分経過 すると死亡率が徐々に上昇し，約 1 時間後には死亡率が $100 \%$ となり，ほとんど救命の可能性を失うことが分かる. ここで，30 回ずつの各シミュレーションにより計測した $\mathrm{T}_{\mathrm{E}}$ の值から, 多量出血の救命曲線よりも以前（事故発生 から 15 分未満）に救命措置の機会を得る受傷者は重傷， 以後（15 分以上）となる受傷者は死亡となると仮定し, 受 傷者の重傷率と死亡率を算出した結果を Fig. 11 に示す.

Fig. 11 (a)より, $2 \cdot 3 \cdot 4 \cdot 6 \cdot 7 \mathrm{kp}$ 地点で事故が発生 した場合のみ救命可能性が存在していることが分かる。 これらの地点は 2 車線以上の道路区間，分岐路が近くに 存在する等の理由から，渋滞が他の地点よりも発生しに くいためと考えられる。ただし，Fig. 11 (b)より救命可 能性の存在する地点に扎いても高津流入ランプから侵入 した場合は，救命可能性がなくなることがわかる。また， 救命措置の開始に時間を要する高津流入ランプ以外から 流入した場合には救命可能性が存在することが Fig. 11 の結果より確認できるが，救命可能性は，すべての場合 において $30 \%$ 以下であり，事故発生から 10 分経過後に 救急車両が高速道路へ流入した場合では，受傷者の救命 可能性は限りなく低くなることが予測できる。

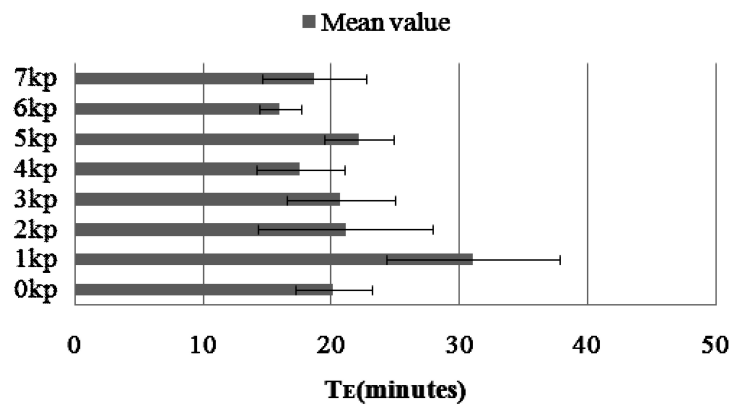

(a) Each kp point

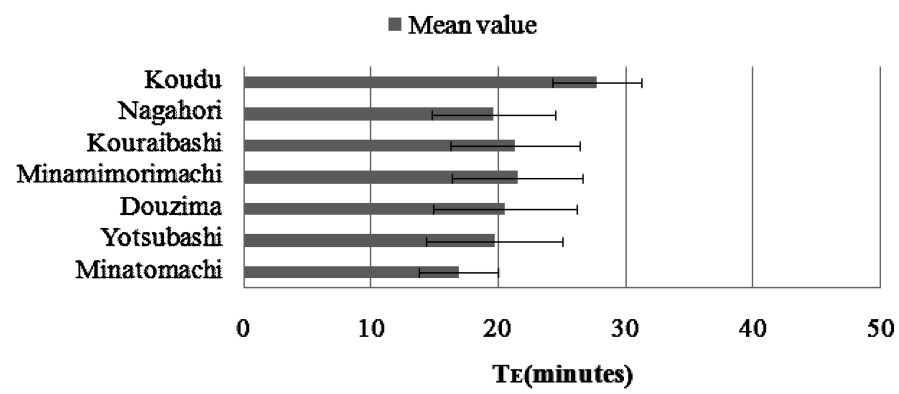

(b) Each enter ramp

Fig. 9 Mean value and standard deviation of $\mathrm{T}_{\mathrm{E}}$ with running support of ambulance. 


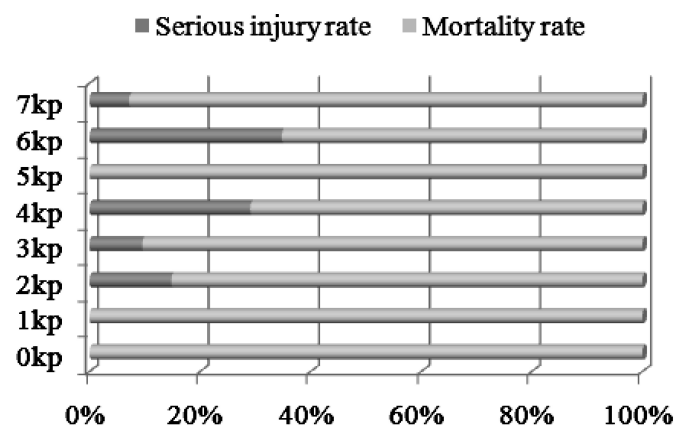

(a) Each kp point
Serious injury rate $\quad$ Mortality rate

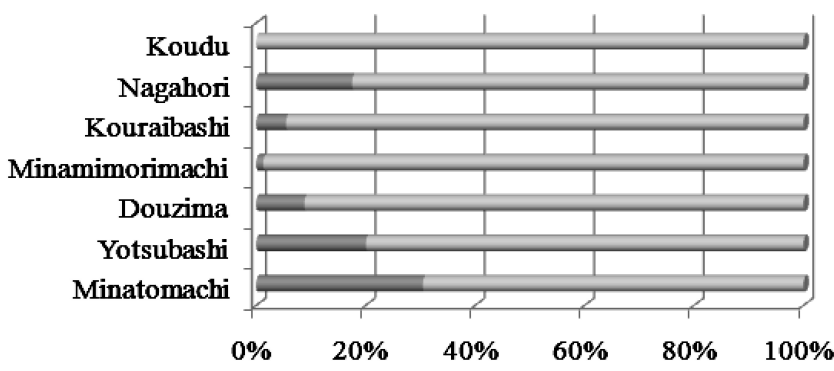

(b) Each enter ramp

Fig. 11 Expected lifesaving effect with running support of ambulance.

\section{4 救急車両の流入時間短縮による救命率向上の検証}

近年，ITS (Intelligent Transportation Systems) 技術の 高度化に伴い，阪神高速道路においても交通センサや高 速道路監視カメラが多数設置され，事故発生時における 被災状況の迅速な把握と，他機関への情報連絡が可能に なっている. 救命活動に打いても，事故発生後の消防機 関への連絡が速い程，救急車両の現場への到着時間が速 くなり，救命可能性も向上すると考えられるが，それが 実証された例は存在しない，元こで本章では，事故発生 から救急車両が高速道路へ流入するまでの時間を短縮化 し，前節よりも 5 分早く流入した場合の $\mathrm{T}_{\mathrm{E}}$ の計測と救命 可能性の検討を行い，前節で実施したシミュレーション 結果と比較し, 迅速な事故状況把握と情報伝達による救 命可能性の向上について検証した．Fig. $12 に \mathrm{~T}_{\mathrm{E}}$ の計測 結果, Fig. 13 にカーラー曲線による救命可能性を示す。
Fig. 12 (a), Fig. 12 (b)の結果より, $\mathrm{T}_{\mathrm{E}}$ の值は改善前 と比較して最大 10 分程, 最小でも 3 分程低下している ことが分かる．1車線の道路区間を走行する必要がある 高津流入ランプから流入した場合の救命活動についても， 改善前よりもその区間の渋滞が小規模であったため, 走 行時間が短縮し, 約 20 分で救命措置を行えることが確 認された。 また，救命可能性についても，Fig. 13 の結 果より, 各 $\mathrm{kp}$ 地点別, 流入ランプ別において，大幅に 向上していることが確認できる．特に，6kp 地点で事故 が発生した場合は，救命措置による死亡率が $0 \%$ となっ ている。午のため，事故発生から 5 分以内であれば，ど の流入ランプから救急車両が流入した場合でも，受傷者 に救命の可能性を与えられる確率が高いことが分かる.

以上の結果より, 生存確率の高い救命活動を行うため に，高速道路管理者は，事故発生後の素早い事故現場の

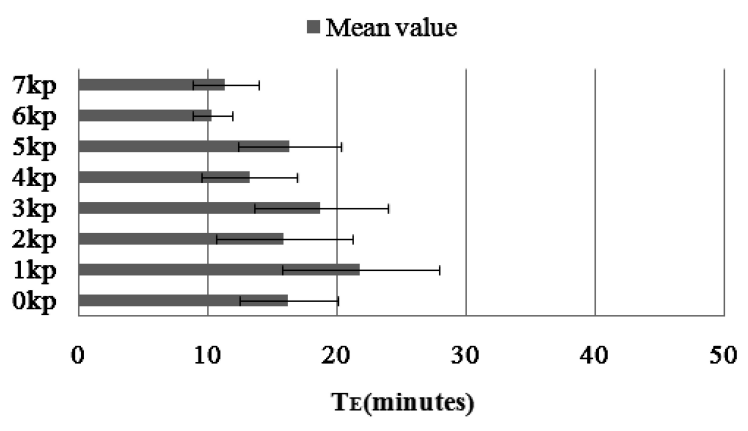

(a) Each kp point

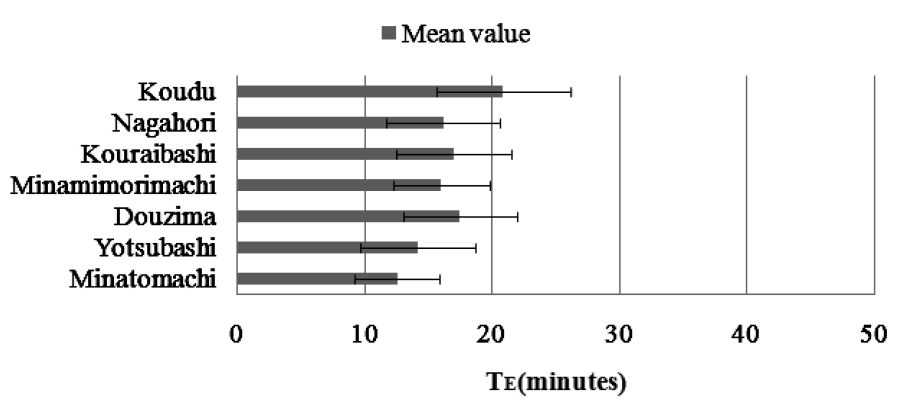

(b) Each enter ramp

Fig. 12 Mean value and standard deviation of $\mathrm{T}_{\mathrm{E}}$ after executing improvement measure.

- Serious injury rate $\quad$ Mortality rate

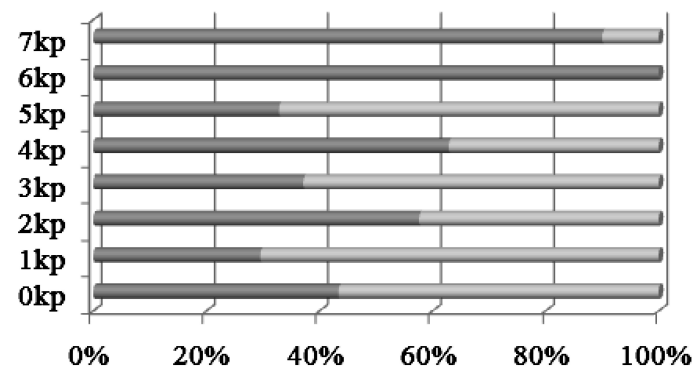

(a) Each kp point

\section{$\square$ Serious injury rate $\quad$ Mortality rate}

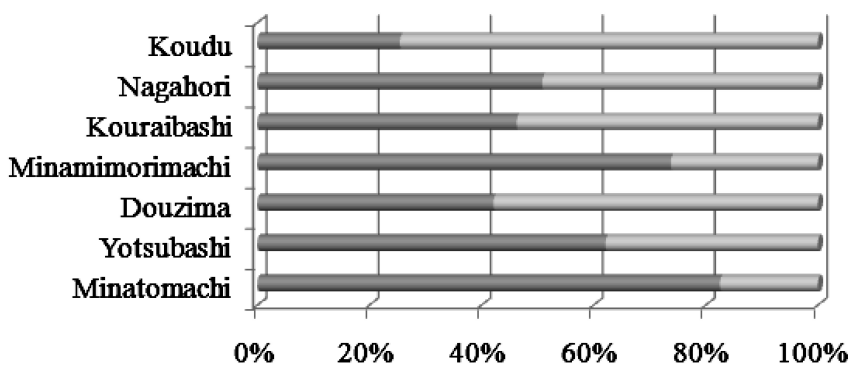

(b) Each enter ramp

Fig. 13 Expected lifesaving effect after executing improvement measure. 
特定，消防機関への迅速な情報連絡，救急緊急車両用の 道路の確保が重要である。そのためには，道路監視カメ ラの増設, ドライバー等への位置情報の提供, 非常電話 機の増設等の改善を実施する事が迅速な救命活動を行う 上で重要であると考えられる。

\section{5 結言}

本研究では，膨大な交通量を誇る都市高速道路におけ る迅速な救命活動を可能にするために，著者らが開発を 進めている交通シミュレーションシステムを用いて，実 際の阪神高速道路における救命活動の有効性と問題点に つい検討した。具体的には，事故発生時の状況と消防 機関による救命活動をシミュレーションシステムで再現 し，救命措置開始時間を計測することにより，救急措置 の開始を遅らせる要因と, 普通・大型車両による救急車 両の走行支援の重要性を明確化した。また，カーラーの 救命曲線を用いて，シミュレーションで実施した救命活 動により，出血多量の受傷者に対する救命可能性がどの 程度存在するのかについて検討した。ささら，救命活動 の改善策として，高速道路への流入時間を短縮化した場 合の救命活動実施状況を再現し，事故発生後の消防機関 への情報連絡が速い程，救命可能性が向上することを証 明した。

しかしながら，本論文で検討した救命活動では，救命 措置実施後の病院への搬送が考慮されていない．受傷者 を救うためには，病院での本格的な治療が最も重要であ ると考えられるので，救急車両が事故現場到着後に高速 道路と一般道路を走行し, 救急病院への搬送が完了する までの時間について考慮する必要がある。また，本論文 で用いたカーラーの救命曲線は, 救命可能性を検討する 上での一つの目安であり, 具体的な症例を通じた医学的 検討も行うことで，より詳細な救命活動の安全性につい て今後検討したいと考えている.

最後に，本研究を実施するに当たり，阪神高速道路(株) 様から貴重な資料の提供を頂くとともに，有益な助言を 賜った。関係各位に御礼申し上げる。また，本研究は， 平成 22 年度文部科学省科学研究費 - 基盤研究 (C) の助 成を受けて実施したものである。関係各位に御礼申し上 げる。

\section{参 考 文 献}

1) S. Saito, N. Koike, Y. Inoue and H. Noguchi, "Effect of emergency service with medical helicopters in a highway accident”, Journal of Safety Problem, Vol.3, pp.125-130 (2008).

2 ) T. Futagami, M. Kashiwadani and M. Watanabe, "The current state and the subject of traffic accidents cognition and ambulance dispatches on a highway”, Journal of Safety Problem, Vol.5, pp.131-136 (2008).

3 ) K. Akieda, Y. Nakagawa, K. Umezawa, M. Motojuku, I. Yamamoto, S. Ino and S. Inokuchi, "Necessity of doctor helicopter mobilization to sick person on expressway", Journal of Japanese Society for Aeromedical Services, Vol.6, No.9, pp.39-43 (2005).

4 ) R. Horiguthi, M. Kuwabara and M. Katakura, "Improvement in traffic flow calculation technique with the traffic simulation system AVENUE”, Annual Meeting of JSCE Infrastructure Planning, Vol.4, pp.452-453 (1996).

5 ) Y. Iida, S. Fujii and T. Uchida, "A dynamic traffic simulation model considering a route choice behavior on road network", Proceedings of JSCE, Vol.536, pp.37-47 (1996).

6 ) M. Okushima, T. Ookubo and T. Daito, "Development of traffic simulation for evaluation of traffic control measure on urban expressway”, Proceedings of Infrastructure Planning, Vol.20, pp.531-538 (2003).

7 ) M. Yamawaki, W. Shiraki, H. Inomo and K. Yasuda, "Development of traffic simulation for urban expressways and its application to business continuity plan”, Journal of Safety Problem, Vol.5, pp.55-60 (2010).

$8)$ M. Yamawaki, W. Shiraki, H. Inomo and K. Yasuda, "Development of traffic simulation system for construction support of BCP in urban expressways", Natural disaster forum at shikoku branch of Japan Society of Civil Engineers, Vol.23, pp.87-94 (2011).

9 ) H.Oouchi, M. Yamamoto and H. Kawamura, "Basis and application of multi-agent system -computing paradigm of complex systems engineering-”, pp.1-15 (2002) Corona Publisher.

10) Hanshin Expressway Company Limited, "New action program for traffic congestion control”, pp.4-7 (2006) 